\title{
Vector-peptide Conjugated Paclitaxel
}

National Cancer Institute

\section{Source}

National Cancer Institute. Vector-peptide Conjugated Paclitaxel. NCI Thesaurus. Code C70971.

A proprietary conjugate of paclitaxel with antineoplastic activity. Similar to the free drug, the paclitaxel moiety in vector-peptide conjug ated paclitaxel binds to and stabilizes tubulin molecules, promoting assembly of microtubules and inhibiting tubulin disassembly which results in the inhibition of cell division. The Kunitz domain-derived vector-peptide carries the conjug ated paclitaxel through the blood brain barrier (BBB), bypassing the transmembrane p-glycoprotein (P-gp) efflux pump, which may result in higher concentrations of paclitaxel in the brain parenchyma. 